a) b) Faculty of Management and Transport, Department of Transport, University of Bielsko-Biala, Poland

\title{
THE INFLUENCE OF TRAFFIC AND METEOROLOGICAL PARAMETERS ASSESSMENT ON NOISE EMISSION
}

\begin{abstract}
The main purpose of that study was an experimental effort to determine the correlation between various traffic and meteorological parameters and sound pollution created as a result of the that traffic.

This paper presents the research results of traffic noise level recorded in the street which is a part of the road system of Bielsko-Biala city. Measured noise data was compared to the registered traffic flows, share of heavy vehicles in the traffic flow and to the velocity of vehicles in the traffic flow. To determine the vehicle velocity from recorded video a velocity detection algorithm was used. It was created based on the MatLab package and allows to determine the vehicle velocity in the movie frame.

The studies are at the first step towards obtaining general assumptions related to the work leading to the formulation of a semi-empirical model of acoustic impact of traffic flow.

The paper shows the strong correlation between traffic flow and sound level. At the same time, it presents a slight impact of the structure and the speed of vehicles on the level of noise. However, weather conditions don't have any influence on the created sound pollution.
\end{abstract}

Keywords: sound pollution, noise, traffic, velocity, impact

JEL: C69 


\section{Introduction}

A level of impact of road transport on the acoustic climate, close to communication routes increases along with the number of vehicles moving on roads. In general meaning, noise is considered to be undesirable, annoying and causing fatigue sounds (Kucharski et al., 2000).

According to the World Health Organization (WHO) (Noise. Data and statistics website, 2019) approximately $40 \%$ of the EU population is exposed to road traffic noise exceeding $55 \mathrm{~dB}$ during the day time. According to the European Commission (Report on the implementation of the Environmental Noise Directive, 2011) costs arising from the impact of traffic noise on public health amount to EUR 40 billion per year.

The methods against road traffic noise can be divided into two groups (State of environment report 2008, 2010; Gronowicz, 2004):

- methods used "at the source", reducing the formation of noise - creating vehicles having a lower sound power, using solutions which reduce emission (e.g. silencers), using modern road surfaces;

- methods reducing the spread of noise - improving acoustic insulation of buildings, construction of road tunnels, acoustic baffles, planning routes with consideration of the acoustic characteristics of the ground, constructing ring roads.

Due to high traffic load of the main arteries of the city, in 2008 in Bielsko-Biala the construction of the north-eastern ring road started. It is a part of the S1 expressway and is designed to increase the capacity and to reduce the degradation of roads in the city by moving traffic into north-south direction. Construction of ring road made it possible to reduce the noise level in the city by about $3-5 \mathrm{~dB}$ (Sordyl, 2013).

The aim of the research presented in this work was to evaluate the impact of traffic parameters on the level of traffic noise on the St. John Paul II Avenue the north-east ring road of Bielsko-Biala city. This street has a transit function in the city traffic system.

The ring road has two lanes in each street and two emergency lanes. It is the expressway of VIth technical grade with design speed of $\mathrm{v}=80 \mathrm{~km} / \mathrm{h}$ (The agreement on the continuation of the construction of S69, 2019). The measuring point was located on the viaduct extending over the ring road (at Wczasowa Street) between Lipnik and Komorowice intersections. The location of Żywiecka Street and the measuring point in the city road system is shown in Figure 1.

In the studied section, the road has four lanes - it is a two-way street with two-lanes each. The width of each lane is 3.5 meters. The S1 is an expressway and it is a part of Trans-European Transport Network. It is also a part of the VI Pan-European Corridor and a part of a TEN-T priority project No. 25 (The agreement on the continuation of the construction of S69, 2019).

The studies are at the first step towards obtaining general assumptions related to the work, which is to lead to the formulation of a semi-empirical model of traffic flow acoustic impact. 


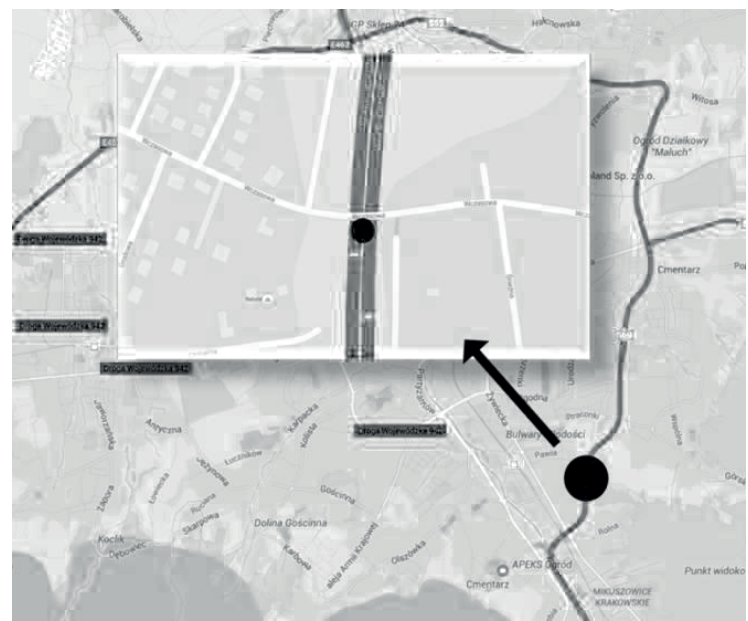

Figure 1. Location of the measuring point in the city road system

Source: (Google Maps)

\section{Measurement methodology}

Noise level tests in the selected location were conducted using a set of measuring equipment adapted for being used in different weather conditions. The measurement set installed at the measuring point includes the following devices:

- microphone stand with all-weather cover;

- Integrating Sound Level Meter SON-50;

- Weather Station Lab-el;

- GoPro Hero3 digital camera.

During tests a SON-50 microphone was placed on a special stand equipped with a microphone extension cable. Before the tests, a calibration of sound level meter was made. Weather Station Lab-el (is a set of sensors for continuous measurement of temperature, humidity, atmospheric pressure, wind speed and direction. The use of the weather station allowed us to perform current assessment of local meteorological conditions that determine the admissibility of measurements (Rozporządzenie, 2011). Permissible limiting values are set out in the Ordinance of the Minister of Environment (Rozporządzenie, 2012) and are shown later in the paper. During the tests the intensity and the generic structure of passing vehicles were recorded with use of a digital camera. The main specification of the measuring equipment is presented in Table 1.

To accomplish the research task, a working day was selected. During it, continuous measurements of equivalent sound level between the hours of 3 p.m. and 5 p.m. were conducted. At the same time, along with noise levels, there were recorded:

- vehicle velocity, traffic volume and the generic structure of vehicles forming a traffic flow (obtained with a digital camera);

- meteorological parameters as wind speed and direction, atmospheric pressure, temperature and humidity (obtained with a weather station). 
Table 1 . The main specification of the measuring equipment

\begin{tabular}{|c|c|}
\hline \multicolumn{2}{|c|}{ Sonometer SON-50 } \\
\hline Accuracy class & 1 \\
\hline Measurement microphone & $1 / 2^{\prime \prime}$ \\
\hline The range of operating temperature & $-10 \div+50^{\circ} \mathrm{C}$ \\
\hline The range of relative humidity & $\leq 90 \%$ (non-condensing) \\
\hline The range of atmospheric pressure & $65 \div 108 \mathrm{kPa}$ \\
\hline Corrective frequency characteristics & A, C, LIN \\
\hline Dynamics characteristics & SLOW, FAST \\
\hline $\begin{array}{l}\text { The total measurement range of equivalent } \\
\text { sound level }\left(\mathrm{L}_{\text {Aeq }}\right)\end{array}$ & $20-135 \mathrm{~dB}$ \\
\hline \multicolumn{2}{|c|}{ Acoustic calibrator KA-50 } \\
\hline Accuracy class & 1 \\
\hline Nominal level of sound pressure & $94.0 \mathrm{~dB}$ \\
\hline Nominal frequency & $1000 \mathrm{~Hz}$ \\
\hline \multicolumn{2}{|c|}{ Weather Station LB-755A } \\
\hline The range of temperature measurement & $-40 \div+85^{\circ} \mathrm{C}$ \\
\hline The range of humidity measurement & $10 \div 95 \%$ \\
\hline The range of pressure measurement & $700 \div 1100 \mathrm{hPa}$ \\
\hline The range of wind speed measurement & $1-100 \mathrm{~m} / \mathrm{s}$ \\
\hline The range of anemometer rotation & $360^{\circ}$ \\
\hline \multicolumn{2}{|c|}{ GoPro Hero3 digital camera } \\
\hline Lens & $\mathrm{f} / 2,8$, wide-angle with reduced distortion \\
\hline Video resolution & from $4 \mathrm{~K}$ (up to $15 \mathrm{fps}$ ) to WVGA (up to $240 \mathrm{fps}$ ) \\
\hline
\end{tabular}

Source: (devices operating instructions)

\subsection{Sound Level Measurement}

Registration of sound level was performed with $1 \mathrm{~Hz}$ frequency and then an equivalent sound level both with background noise were calculated.

As the continuous measurements were performed with periodic registration of $\mathrm{L}_{\text {Aeq tk }}$ sound level, the calculation of equivalent sound level with acoustic background $\mathrm{L}_{\text {Aeq0T }}$ for 2-hour time reference covering a wide range of periods of registration, requires to use the following conversion (Rozporządzenie, 2011):

where:

$$
L_{\text {Aeq } 0 T}=10 \log \left[\frac{1}{T} \sum_{k=1}^{n} t_{k} 10^{0,1 L_{\text {Akiq }}}\right]
$$

$\mathrm{T}$ - reference time interval [s],

$\mathrm{t}_{k}$ - the period of registration results [s],

$\mathrm{L}_{\text {Aeq } t k}$ - equivalent sound level A-weighting during the period of recording results $\mathrm{t}_{k}$ in decibels [dB],

$\mathrm{n}$ - the number of results registration periods $t_{k}$. 
The next step is to determine the reference noise generated by other sources than road vehicles when its impact cannot be eliminated at the time of measurement. In this paper for the reference sound level a minimum value of measured noise level was assumed which occurred during the corresponding 2-hour reference time intervals.

Determination of equivalent sound level A-weighting for the reference time interval requires to use the following conversion (Rozporządzenie, 2011):

$$
L_{\text {Aeq } T}=10 \log \left(10^{0,1 L_{\text {Aeq } 0 T}}-10^{0,1 L_{\text {AeqT }}}\right)
$$

where:

$\mathrm{L}_{\text {Aeq Ref }}$ - reference sound level in decibels $[\mathrm{dB}]$.

\subsection{Speed measurement}

An important issue is the correlation of noise with the speed of passing vehicles. For this purpose, video material gathered with the GoPro Hero3 digital camera was used. The movie was converted and resulted in 5-minute sequences with parameters:

- resolution: $720 \times 404$ pixels;

- 59.941 frames per second;

- 17985 frames in all sequence.

The most preferred method of detecting the speed of passing vehicles included in the sequence of the film is the use of optical flow method. It involves the movement of the gray values of each pixel in successive frames of the film. The general condition of the optical flow is given by the equation:

where:

$$
-\frac{\partial I}{\partial t}=\frac{\partial I}{\partial x} u+\frac{\partial I}{\partial y} v
$$

$I(x, y, t)$ - brightness value of a point $(x, y)$ at time $t$,

$u, v$ - pixel speed in vertical and horizontal directions.

In this case an important parameters are the spatial brightness changes, $\frac{\partial I}{\partial x}$ and $\frac{\partial I}{\partial y}$.

Features enumerating these parameters of optical flow are available in the software package MatLab. The library used in further calculations is OpticalFlow form package Vision.

In order to make calculations, it was necessary to develop an appropriate algorithm. After preliminary tests, it turned out that the frame of the camera is too broad and the ancillary items such as noise barriers give too much noise. Therefore, it was decided to quantize computing area and next isolate two sub-areas where vehicles are detected in opposite directions separately. The final area calculation is shown in Figure 2. 


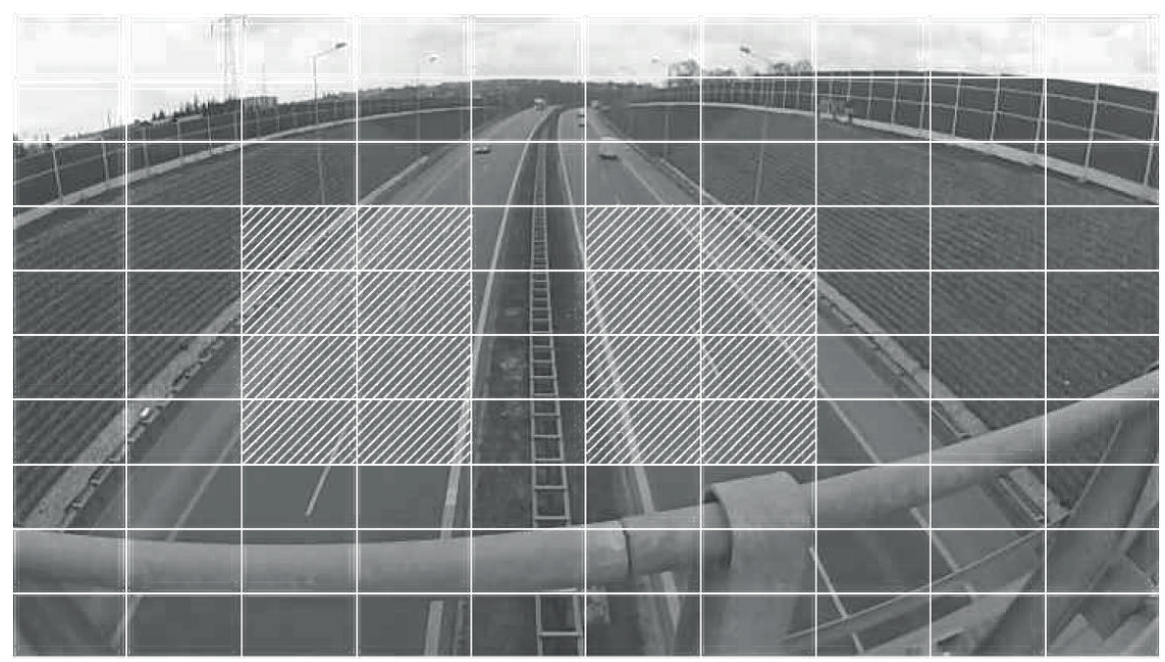

Figure 2. Motion detection areas in the frame of the movie Source: (own elaboration)

In each frame, optical flow for all pixels was calculated and then applied to the film. For clarity of calculations, it has been decided to apply to the film only the vertical component of the speed of moving objects. Then the MatLab algorithm made appropriate adjustment of the speed by angles of boundary lanes for each direction separately.

Correction factors used to make adjustments:

$$
\text { speed }=u \cdot \frac{1}{\sin \alpha}
$$

where $\sin \alpha$ is an angle between the vertical component of velocity and overall speed:

$$
\begin{gathered}
\text { speed }_{\text {left_sde }}=u \cdot \frac{1}{\sin \left(50,3^{\circ}\right)}=u \cdot 1,3 \\
\text { speed }_{\text {right_side }}=u \cdot \frac{1}{\sin \left(-29,4^{\circ}\right)}=u \cdot(-2,04)
\end{gathered}
$$

The MatLab code of above is written as follows:

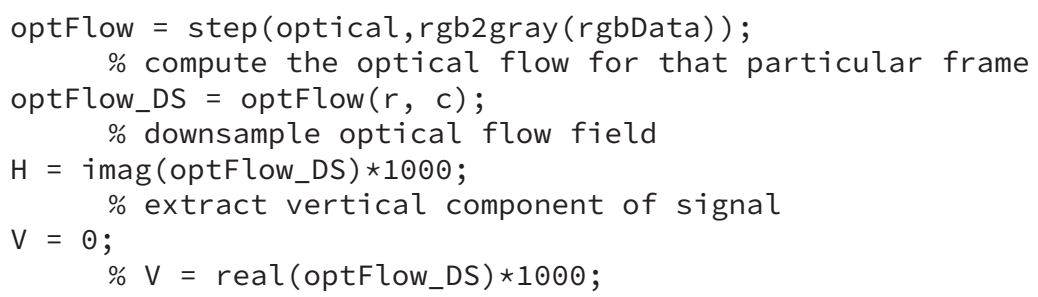


The optical flow is computed for each frame averaged within the two separate blocks. Noise value occurring within the read blocks is ignored:

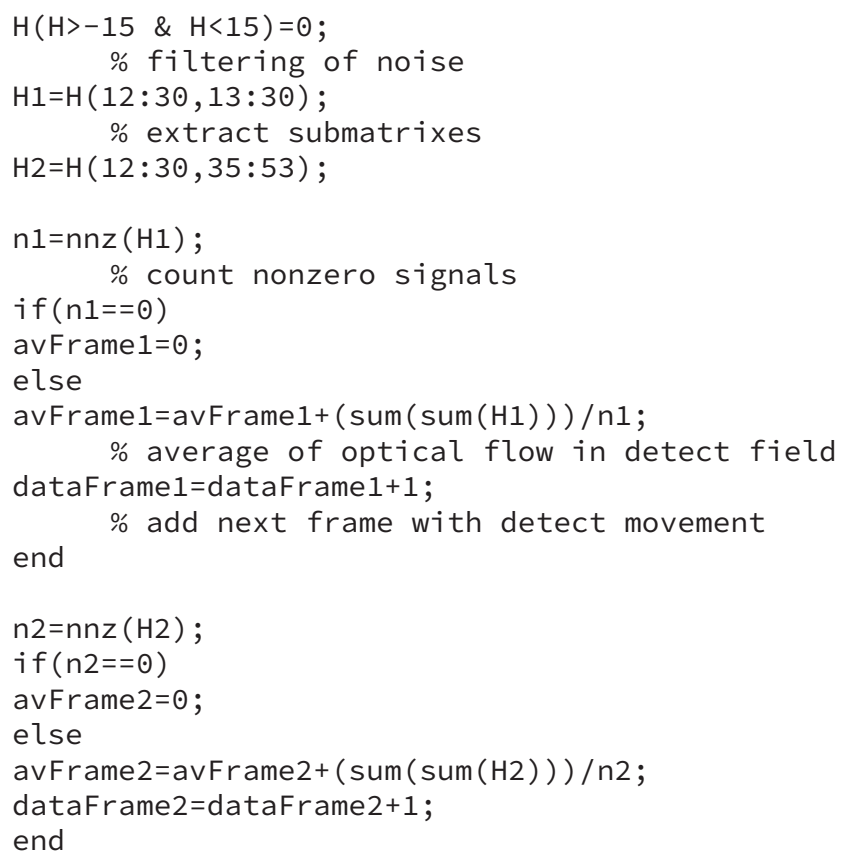

The next step is to average the flow for every second. For the convenience of calculation it was accepted that each second of film has 60 frames:

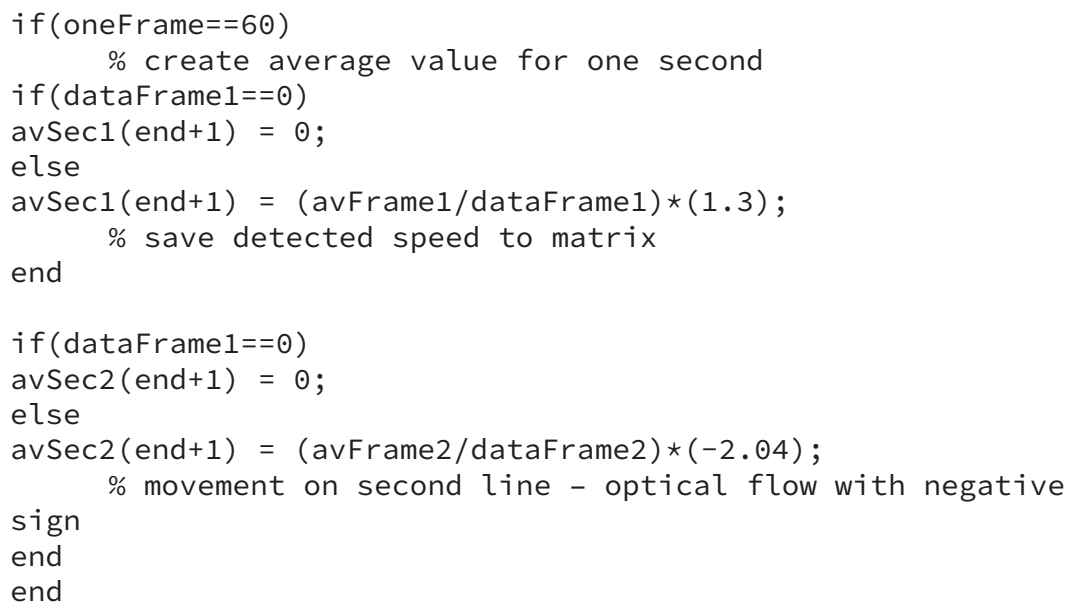

The effect of algorithm work is shown in Figure 3. The results are continuously saved as a CSV file. 


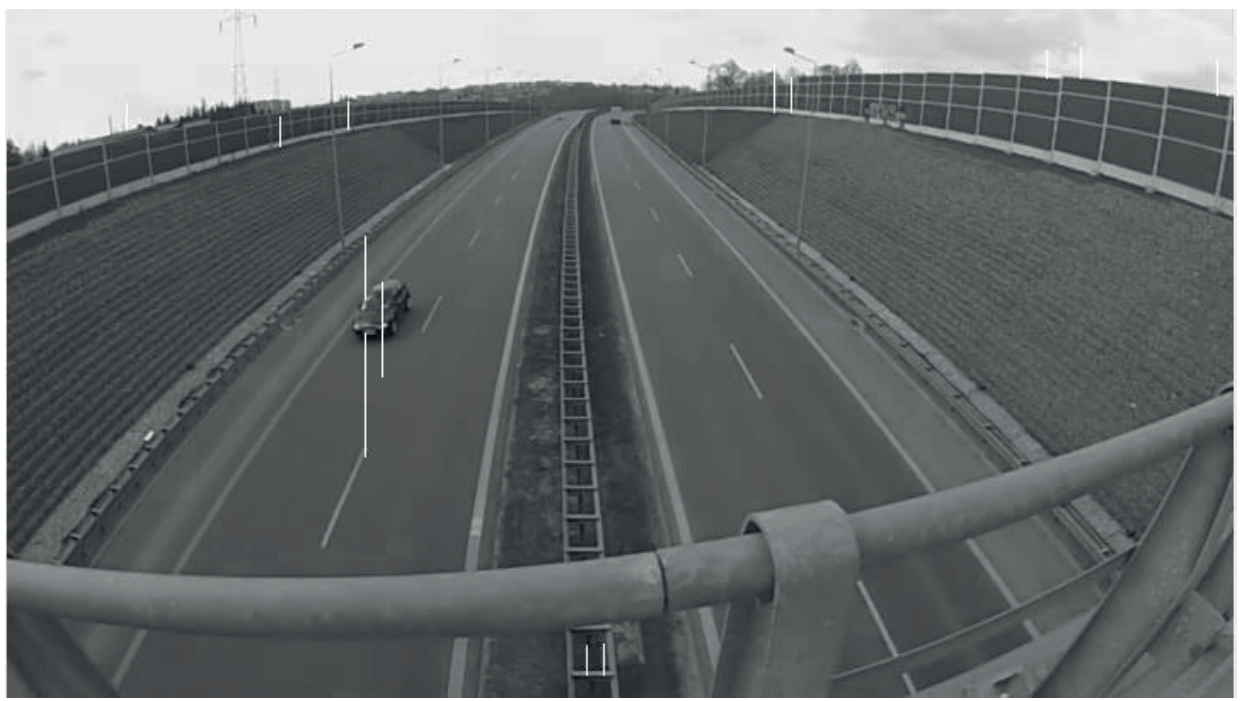

Figure 3. The optical flow of the vehicle moving in the frame Source: (own elaboration)

\section{Tests results}

The registered times of occurrence of particular noise level classes in percentage terms are shown in Figure 4. The results indicate that noise levels exceeding $65 \mathrm{~dB}$ - max value permitted in Polish law regulations (Rozporządzenie, 2012) were recorded at $85 \%$ of the measurement time.

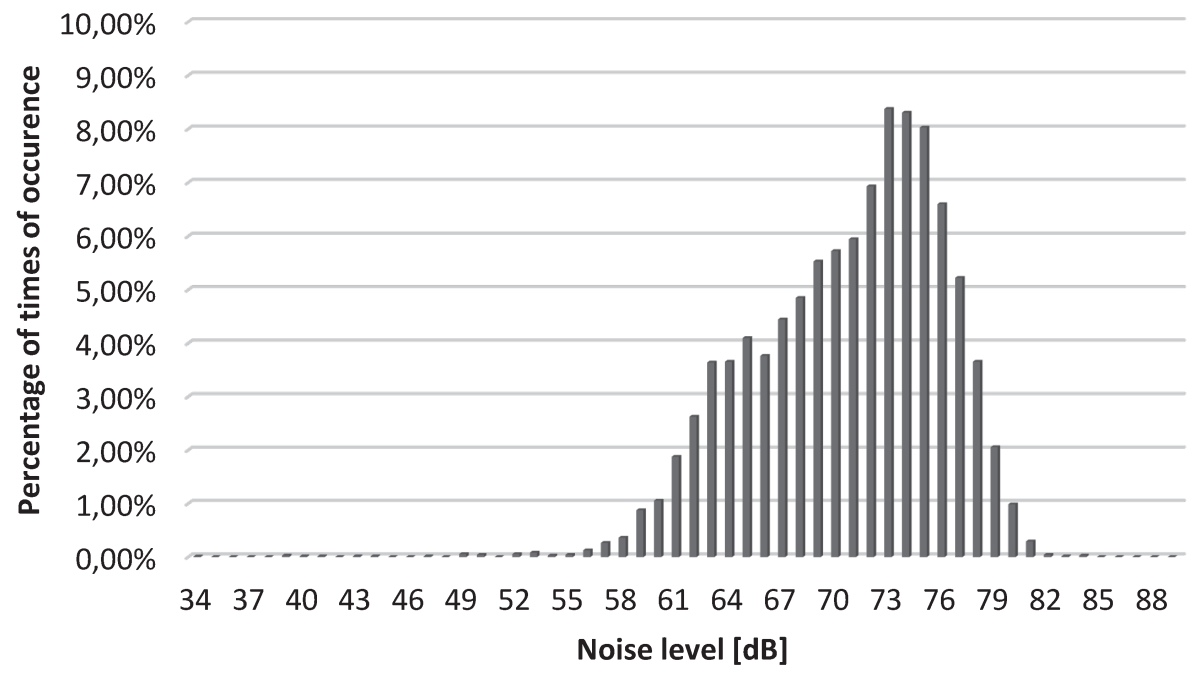

Figure 4. Times of occurrence of particular noise level classes in percentage terms Source: (own elaboration) 
Table 2 combines equivalent sound levels $\mathrm{L}_{\text {Aeq }}$ calculated for the 2-hour time period with the total number of vehicles and the number of vehicles divided into two basic categories.

Table 2. Comparison of equivalent sound level $\mathrm{L}_{\text {Aeq }}$ with traffic flow

\begin{tabular}{|l|c|}
\hline \multicolumn{1}{|c|}{ Parameter } & The average number of vehicles per hour \\
\hline Total & 1616,5 \\
\hline Passenger vehicles and motorcycles & 1309,5 \\
\hline Delivery vehicles, trucks, buses, other & 307 \\
\hline Equivalent sound level $\mathrm{L}_{\text {Aeq2h }}[\mathrm{dB}]$ & 72,5 \\
\hline
\end{tabular}

Source: (own elaboration)

Figure 5 compares the average noise level with reference to the traffic flow, with division to the generic structure of the vehicles. It is easy to notice the correlation between the sound level and traffic flow, especially for the bottom parts of sound lane.

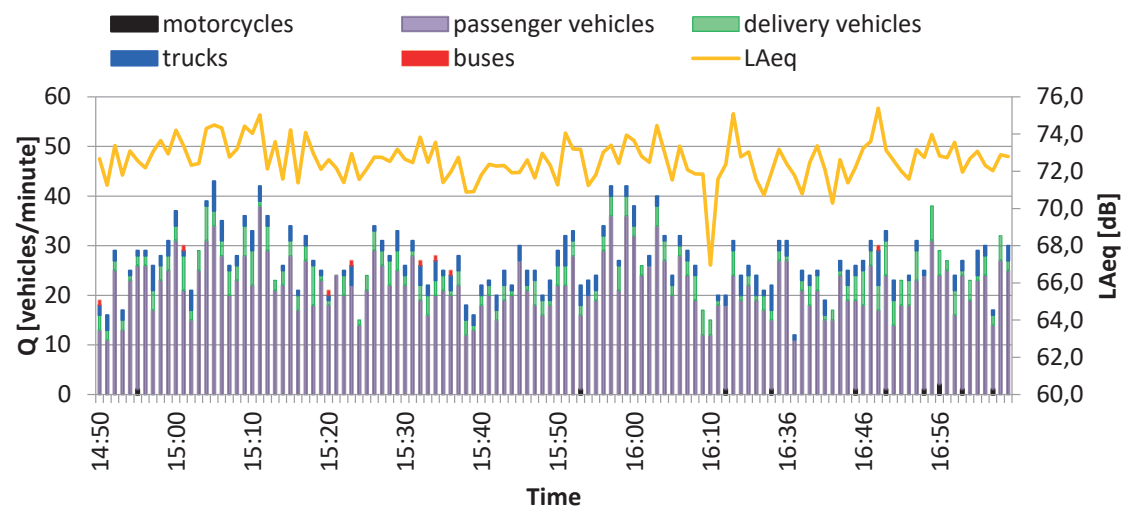

Figure 5. Comparison of traffic flow to the average noise levels

Source: (own elaboration)

Comparison of the calculated equivalent noise level with reference to the registered traffic flow for each test minute is shown in Figure 6. The value of the correlation coefficient (Table 3) indicates the existence of strong positive interdependence of noise level on traffic flow.

Obtained dependence of the calculated equivalent noise level with reference to share of heavy vehicles (calculated as the sum of delivery vehicles, trucks, buses and other special vehicles) for each test minute is shown in Figure 7. A small value of the correlation index (Table 3 ) indicates a weak relation between registered sound level and the structure of the vehicle in the traffic stream. 


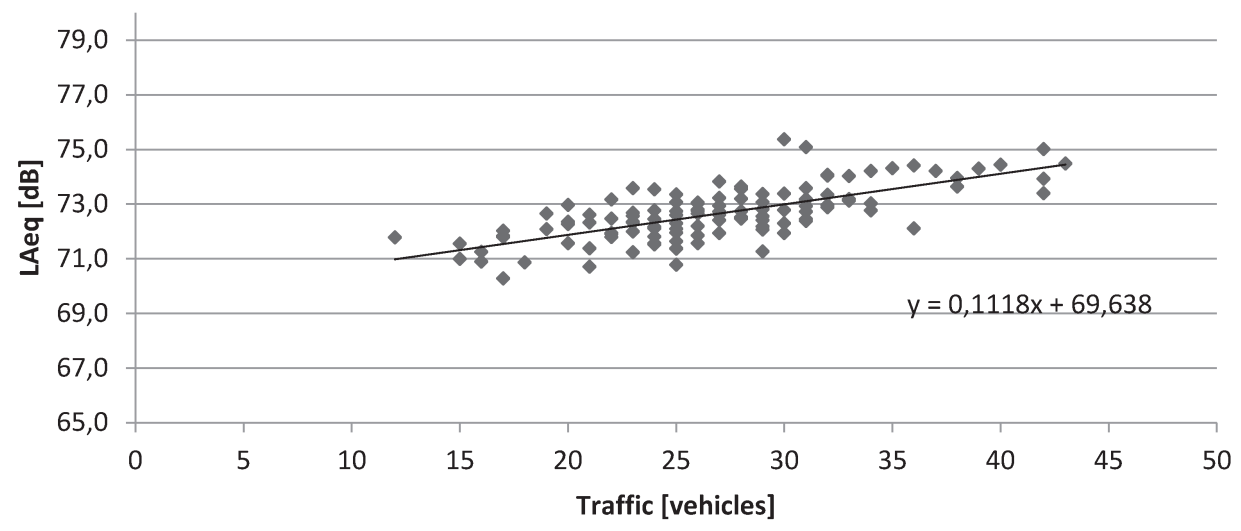

Figure 6. Comparison of equivalent sound level $\mathrm{L}_{\text {AeqT }}$ to traffic flow with defined trend line Source: (own elaboration)

Table 3. Correlation of recorded data

\begin{tabular}{|l|c|c|c|}
\hline \multicolumn{1}{|c|}{ Parameter } & $\mathrm{L}_{\text {Aeq }}$ & Traffic flow & Share of heavy vehicles \\
\hline $\mathrm{L}_{\text {Aeq }}$ & 1.00 & & \\
\hline Traffic flow & 0.68 & 1.00 & 1.00 \\
\hline Share of heavy vehicles & 0.10 & -0.08 & \\
\hline
\end{tabular}

Source: (own elaboration)

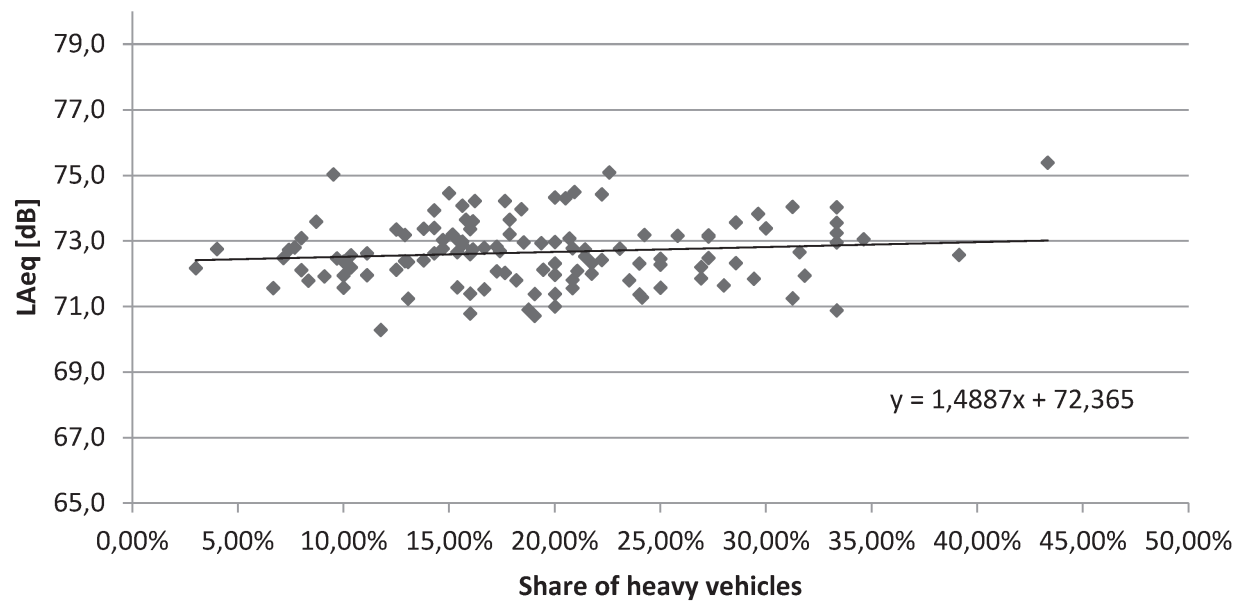

Figure 7. The dependence of the calculated equivalent noise level with reference to share of heavy vehicles with defined trend line Source: (own elaboration) 
Figure 8 shows the dependence of the equivalent sound level $\mathrm{L}_{\text {AeqT }}$ with reference to vehicles velocity. The obtained correlation coefficient of 0.11 indicates a weak positive correlation. However, it must be kept in mind that the equivalent sound level is indicated in a logarithmic scale.

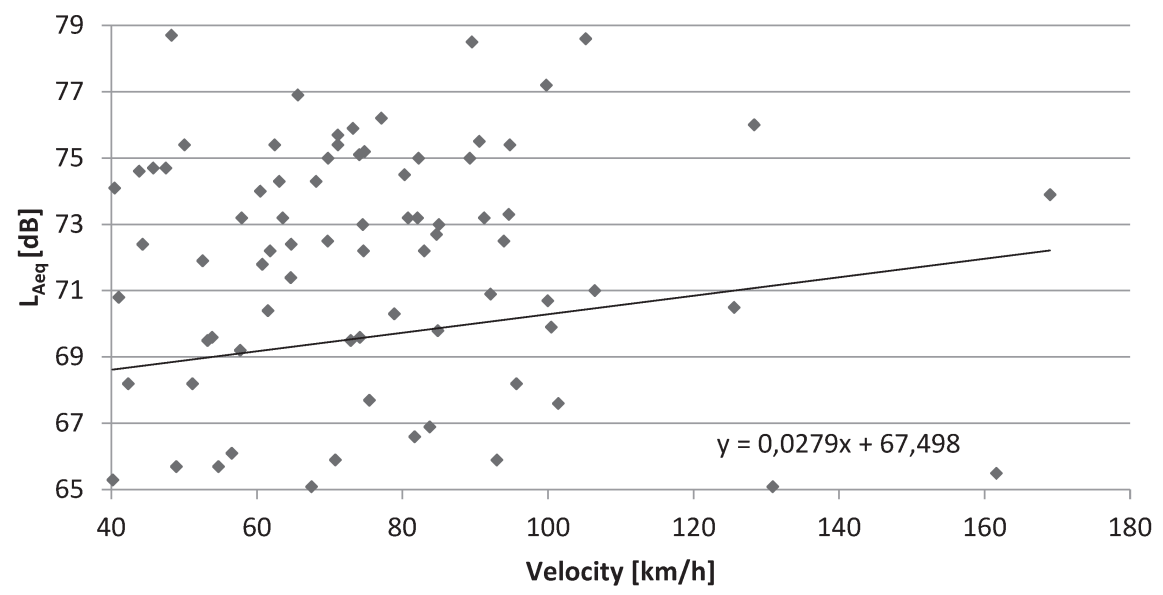

Figure 8. The dependence of the calculated equivalent noise level with reference to vehicles velocity with defined trend line

Source: (own elaboration)

\section{Conclusions}

It was noted that the impact of meteorological parameters on recorded sound levels is not defined and difficult to determine with such small amount of collected data. However, the use of the weather station, enabled immediate evaluation of the local weather measurement conditions. The limit of meteorological parameters were not exceeded. The acceptable limit values of meteorological parameters are defined in the Ordinance (Rozporządzenie, 2011) and are shown in Table 4 both with parameters recorded during the test.

Table 4. The conditions under which the measurements may be conducted both with recorded meteorological parameters during test

\begin{tabular}{|l|c|c|}
\hline \multicolumn{1}{|c|}{ Parameter name } & The limit values & The values recorded \\
\hline Temperature & $-10^{\circ} \mathrm{C} \div 50^{\circ} \mathrm{C}$ & $16-23^{\circ} \mathrm{C}$ \\
\hline Relative humidity & $25-98 \%$ & $60-75 \%$ \\
\hline Wind speed & $0-5 \mathrm{~m} / \mathrm{s}$ & $0-4,8 \mathrm{~m} / \mathrm{s}$ \\
\hline Atmospheric pressure & $900-1,100 \mathrm{hPa}$ & $969-972 \mathrm{hPa}$ \\
\hline Precipitation & Lack & Lack \\
\hline
\end{tabular}

Source: (own elaboration; Rozporządzenie, 2011) 
An acceptable level of noise in the study area for the day $\mathrm{L}_{\text {AeqD }}$ (counted from 6 a.m. to 10 p.m.) is $65 \mathrm{~dB}$ (Rozporządzenie, 2012). Registered equivalent sound level $\mathrm{L}_{\text {Aeq2h }}[\mathrm{dB}]=72,5 \mathrm{~dB}$ indicates that the permissible sound levels are temporary exceeded. To check whether the exceedings are not permanent, a research during full 16 hour time period should be done.

The analysis of recorded research material indicates the existence of a strong dependence of the calculated equivalent noise level with reference to traffic flow. What is unusual, there is a small correlation between sound level with reference to the generic structure of vehicles in the traffic stream. This may be caused by the peculiarity of the test road section, where trucks most often ride with constant, maximum velocity $(90 \mathrm{~km} / \mathrm{h})$, set on cruise control.

The analysis of recorded research material indicates the existence of a small dependence of the calculated equivalent noise level with reference to vehicle velocity.

\section{References}

European Comission (2011), Report from the commission to the European Parliament and the Council on the implementation of the Environmental Noise Directive in accordance with Article 11 of Directive 2002/49/EC, COM(2011) 321 final, Brussels 2011. Available from https://eur-lex. europa.eu/LexUriServ/LexUriServ.do?uri=COM:2011:0321:FIN:EN:PDF.

Generalna Dyrekcja Dróg Krajowych i Autostrad (2014), Umowa na kontynuację budowy S69 Mikuszowice-Żywiec podpisana. Available from http://www.gddkia.gov.pl/pl/a/15474/ Umowa-na-kontynuacje-budowy-S69-odc-w-MikuszowiceZywiec-podpisana [Accessed 10 April 2019].

Główny Inspektorat Ochrony Środowiska (2010), Raport o stanie środowiska w Polsce 2008, Biblioteka Monitoringu Środowiska, Warszawa. Available from http://www.gios.gov.pl/ stansrodowiska/upload/file/pdf/download/soer_pl_2008_polski.pdf.

Gronowicz, J. (2004), Ochrona środowiska w transporcie lądowym, Instytut Technologii Eksploatacji, Poznań-Radom.

Kucharski, R. J., Taras, A., Chyla, A. et al. (Eds.) (2000), Zanieczyszczenie środowiska hałasem w świetle badań WIOŚ w 1999 roku, Inspekcja Ochrony Środowiska, Warszawa.

Program ochrony środowiska przed hałasem dla miasta Bielska-Białej (2004), Zabrze.

Rozporządzenie Ministra Środowiska z dnia 1 października 2012 r. zmieniające rozporządzenie w sprawie dopuszczalnych poziomów hałasu w środowisku (Dz. U., poz. 1109).

Rozporządzenie Ministra Środowiska z dnia 16 czerwca 2011 r. w sprawie wymagań w zakresie prowadzenia pomiarów poziomów substancji lub energii w środowisku przez zarządzającego drogą, linią kolejową, linią tramwajową, lotniskiem lub portem (Dz. U. Nr 140, poz. 824).

Sordyl, J. (2013), Badania poziomu hałasu komunikacyjnego w warunkach szczytu komunikacyjnego, TTS Technika Transportu Szynowego, 10, 2969-2975.

WHO, Noise. Data and statistics. Available from http://www.euro.who.int/en/health-topics/ environment-and-health/noise/data-and-statistics [Accessed 10 April 2019].

\section{Corresponding author}

Marcin Honkisz can be contacted at: mhonkisz@ath.eu 